\title{
THE CONNECTEDNESS BETWEEN ORGANIZATIONAL TIME/SPACE AND EXPERIENCED TIME/SPACE FROM THE PERSPECTIVE OF AN ONLINE DISTANCE STUDENT
}

\author{
Tran Thi Ngan* \\ VNU University of Languages and International Studies, \\ Pham Van Dong, Cau Giay, Hanoi, Vietnam \\ Received 1 November 2019 \\ Revised 15 November 2019; Accepted 20 December 2019
}

\begin{abstract}
This research problematizes the conception of time and space in online distance education. It argues that online distance education is constructed from different times and spaces, namely those as organized by the institutions and those as experienced by the distance learners. In essence, it seeks to unfold how these organizational time and space and the experienced time and space are connected or separated, from the learners' perspective. It employs a narrative inquiry to recount the experience of a 32-year-old British man pursuing a distance learning course. In doing this, the research aims to identify how online learners are engaged with the course that they are taking with respect to time and space, as well as pinpointing the gaps that separate them from the course. With consideration of those aspects in mind, online distance courses could be more effectively organized in such a way that enhances student motivation, commitment and resilience, thus contributing to their overall experience of digital learning.

Key words: connectedness, time and space, translocality, transtemporality, online distance learning, digital education
\end{abstract}

\section{Introduction}

"In order to understand the educative process online, one must examine those who shape it" (Kabat, 2014). In this day and age when online distance education has seemingly become a "savior" for in-service workers wishing to pursue a higher degree or advance their professional knowledge (Raddon, 2006), more attention is paid to exploring the learners' digital learning experience. To understand students' experience, according to Sheail (2017), will involve taking into account the multifaceted manifestation of time and space of the university where they study. In

\footnotetext{
Tel.: 84-903456920
}

Email: ngantranvnu@gmail.com such a manifestation, the university exists neither only in the physical time and space of an institution, nor "anytime, anywhere" as commonly conceived of. In such a manifestation, there exist different times and spaces that both connect and separate the online learners from the learning course.

As Raddon (2006) has put it, "the idea of physical and spatial separation across time and space is often used to differentiate distance learning from so-called 'traditional' forms of education" (p. 157), research into digital education should not overlook these fundamental time and space aspects. While there have been significant works on time and space in online education, such as Barberà and Clarà (2012); Barberà and Clarà (2014); 
Barberà, Gros, and Kirschner (2015); Bayne, Gallagher, and Lamb (2014); Fielding (2016); Hall (1983); Kahu, Stephens, Zepke, and Leach (2014); Leeds (2014); Raddon (2006); Ross, Gallagher, and Macleod (2013); and Sheail (2017), little has been studied about how different types of times and spaces are connected or separated. Studying these connectedness and separation aspects, I propose, will add meaning to both educational practices and administration procedures. Thus, this research seeks to delve into the online distance learners' experience regarding the connectedness between the organizational time and space and their own experienced time and space. It aims to identify how online learners are engaged with the course that they are taking with respect to time and space, as well as pinpointing the gaps that separate them from the course. With consideration of those aspects in mind, online distance courses could be more effectively organized in such a way that enhances student motivation and commitment, thus contributing to their overall experience of digital learning.

\section{Literature review}

Topics concerning time and space in digital education have been discussed among a growing body of studies (cf. supra) as researchers are growingly intrigued by how time and space typify this particular form of education. Contrary to the idea of "anytime, anywhere" as usually claimed, what Fielding (2016) referred to as "the myth of universal access" in online education (p. 103), the concepts of time and space have in recent years received more nuanced interpretations.

Time is hardly explicitly dealt with in research about online education (Barberà et al., 2015). In their systematic review, however, Barberà et al. (2015) have identified that three themes related to time are usually focused on: time efficiency, time use, and pace of learning (Barbera et al., 2015). The questions asked mostly pertain learning more in the same time, learning the same in less time, patterns of time management, or differentiated learning pathways within digital education. In the recent attempts to bring more nuances to the notion of time, several researchers have paid closer attention to the learners' experience regarding time. For example, Kabat (2014) and Oztok et al. (2014) have challenged the conventional dichotomy of time as being synchronous and asynchronous. By investigating the students' discussion board, Oztok et al. (2014) found that there the time is displayed to the students both linearly and non-linearly. For some other researchers, such as Khoo and Cowie (2014), an interest was in how pivotal time points of the postings in the discussion board can impact the reflection and collaboration procedure, as well as offering socio-emotional support for the online students.

With regard to space, in their narrative study, Bayne et al. (2014) attempted to discover how online distance students translate the space of the physical university campus into their own version of "space". The researchers identified the significance of the physical campus through its "topological multiplicity" (p. 581): the sentimental campus, the metaphysics of presence or "campus envy", and the imagined campus. In particular, the students experience the space of the university as a sentimental campus when they associate their presence at the university with the "homing" impulses, such as a connection their family members or themselves have with the university. In another scenario, the physical campus is spatially represented as "a guarantor of the authenticity of academic experience" (p. 577), a kind of space online students are "jealous" of from a distance. Apart from that, the university also spatially exists 
in the imagination of the online students as they perform their study tasks in, for example, at home or the hotel room of their business trip, or simply anywhere with an access to fast internet connection. The identification of these three topologies suggests that the concept of space in online education is complex and highly personalized, which necessitates further explorations in order to unveil what it means to be "at university" for an online distance learner.

A number of other studies, by various approaches, have combined time and space in their attempt to understand the learners' experience in digital learning. Kahu et al. (2014), for instance, explored how adult learners learned to manage their space and time to sustain their engagement in the online learning course. Raddon(2006), in interpreting narratives of distance students, concluded that the separation across time and space can be viewed as an opportunity, which gives the learners a sense of control and allows them to pursue their studies while still committed to other social and familial roles. In her recent study, Sheail (2017) brought together the concepts of translocality and transtemporality to locate the digital university in different locales. While the presence of the digital university in Bayne et al.'s (2014) discovery was only in terms of space, Sheail's (2017) representation brought it into existence in both space and time, whether in the car park, in the curfew, or in the electric generator.

The aforementioned studies have provided a snapshot of how time and space are researched in online distance education. My work here is to complement them and bring together an understanding of time and space from both the organizational and experienced aspect. A conceptual framework is built on the basis of the definitions of time and space by Sheail (2017). There the concepts of time and space are treated as "connected" and "multiply layered", thus creating a complex "location" for the digital institution (Sheail, 2017 , p. 2). Central to her definitions are the ideas of translocality and transtemporality, which serve as a starting point for further concepts to be linked.

Greiner and Sakdapolrak (2013) defined translocality as "phenomena involving mobility, migration, circulation and spatial interconnectedness not necessarily limited to national boundaries" (p. 373). Froma translocal perspective, they stated, the "diverse and contradictory effects of interconnectedness between places, institutions and actors" could be captured. This "connectedness" aspect is shared in Sheail (2017) explanation of the term as "a common state of being, or feeling, connected to other places" (p. 4). In this sense, it could be understood that regardless of their geographical distance, there exists a connection between a student taking an online course and the university where the course is offered. In the present study, the concept of translocality in distance learning is scrutinized from two layers - organizational space and experienced space. The organizational space is defined as the space organized by the course providers. From the physical side, it involves the campus of the institution. From the digital side, I also consider the learning platform as part of the organizational space, which includes, for example, the presentation of and access to learning contents, the communication tools and support facilities, etc. On the other hand, the experienced space is understood as the place where the students' study takes place and its surroundings. On a larger scale, I also take into account the socio-political situation of the country where the student resides as an aspect of their experienced space. 
Of equal importance to the concept of translocality, Sheail (2017) proposed the term transtemporality to "emphasize the coexistence of different 'times' when considering translocality and the university, particularly in a digital context" (p. 5). She elaborated:

These times include not only the practical time differences in making translocal connections, across time zones, but also the experiential times of individual accounts, as well as the multiple political and cultural times, the 'times we live in', which might be significant to the practices of a digital education which aims to engage students and staff in multiple locations, while bringing them together in digital environments (p. 5).

From the aforementioned definition of transtemporality, "time" in online distance education is investigated as organizational time and experienced time. The concept of organizational time describes time as designed by the course providers, which includes, but not limit to: the time allocated to the course, to specific study contents and learning activities, as well as the time of the institution where the course is based. The experienced time, on the other hand, involves the time set aside by the students for studying the course and how they arrange their study activities and fit them in their daily schedules. I also take into account the socio-political context of the country where the students reside as an aspect of their experienced time.

\section{Research design and methodology}

\subsection{Research approach}

With the belief that knowledge is constructed and given meaning through social settings, social constructionism has been adopted as the philosophical paradigm of the research. Taking this stance emphasizes the role of both the subject and the researcher as co-constructors of knowledge through the process of dialogue and negotiation (Savin-Baden \& Major, 2013). Congruent with social constructionism, as indicated by Savin-Baden's and Major's (2013) Wheel of Research Choices, is the focus on individuals as the phenomenon of study and the use of narrative as a major research method. Therefore, in the present study which involves exploring how online learners perceive the connectedness or separation between the organized time and space of the institution and the real-life experienced time and space, this set of research lenses proves its appropriateness. It is by means of a narrative inquiry that we can "do research into an experience" as we "experience it simultaneously" (Clandinin \& Connelly, 2000 , p. 50), that we can have an "entry into this 'lived experience' of individuals, facilitating perspectives that embrace the multiplicity and polyvocality of reality" (O'Shea, 2014, p. 140). Moreover, a narrative inquiry, with its "evaluative and explanatory value", will facilitate the meaning-making process between the researcher and the participant (O'Shea, 2014, p. 141), therefore, enabling a deep exploration of the subject's perspective, attitude, experiences and construction of knowledge.

The choice of narrative in this research is two-fold, with narratives being not only a research approach but also a primary source of data (Savin-Baden \& Major, 2013). With the focus on an individual's experiences, the study relies on the participant's stories as they "entail a significant measure of reflection on either an event or experience, a significant portion of a life, or the whole of it" (Freeman, 2006). An important aspect of narrative, as Freeman (2015) argues, is the 
"retrospective dimension", which I believe allows for a retrieval of events that facilitate the construction of knowledge (p. 40). To be more specific, as Savin-Baden \& Major (2013) put it, "the point of collecting stories is to understand the experiences and the way they are told, seeking clarity about both the events that have unfolded and the meaning that participants have made of them" (p. 231). Moreover, storytelling involves a significant contribution of personal perspectives, therefore the researcher could form a better understanding of the individual as a research phenomenon.

\subsection{Sampling and data collection}

The research discusses data from a single participant, hereinafter referred to as Gaz, who is currently enrolled in a Post Graduate Certificate of Education course predominantly UK-based. In order to ensure the anonymity of the institution, the university will be referred to as UniName University throughout this report.

Gaz is originally from Leicester, England, who is now living and working in an international school in Hanoi, Vietnam. He is 32 years old, married and currently living with his wife and a new-born child. Gaz was chosen as the research participant by means of convenience sampling for three main reasons: First, he meets the research's initial criteria of choosing a participant who is currently taking an online course with the duration of minimally one year. Second, time constraint in conducting the research somehow has limited the choice of participants to someone who is most accessible. Third, given the fact that qualitative research approaches appreciate the uniqueness of individual experiences, data collected from participants are meaningful in themselves without necessarily being strictly representative for a particular group of people (Savin-Baden \& Major, 2013).

Regarding research instruments, a semi-structured interview protocol was constructed, which consists of two main parts with 23 questions. The first part serves as an icebreaker, asking general questions in order create rapport and a comfortable atmosphere for experience sharing. By doing this, stories could be told with fidelity (Flick, 2014), thus enhancing the quality of the data obtained. The second part deals with more detailed questions about the time and space of the digital course with regards to both the organizational and experienced aspect. Concepts were clearly defined to avoid any possible ambiguity for the interviewee. The interview was conducted digitally, by means of Skype, and recorded with the application Call Recorder. However, after that, there arose more ideas during the transcription process, which made me decide to ask Gaz several additional questions in written form using Facebook Messenger. He was very responsive and replied one day afterwards.

The whole data collection procedure was done with ethical considerations. An informed consent form was sent to the participant before the interview. The interview was done within 90 minutes, with respect for privacy, i.e. the subject's beliefs, attitudes and opinions. Crosscultural considerations in communication were also taken into account, given the cultural background difference between the subject and the researcher. Moreover, in order to ensure the transparency of the process, I attempted to engage myself as the researcher in the "self-disclosure", as well as "striving for a clear view of what participants mean while simultaneously seeking and acknowledging co-created meaning" (Savin-Baden \& Major, 2013). 


\subsection{Data analysis and interpretation}

Data collected from the interview were transcribed into 26 A4-sized pages and coded manually in two cycles. In the first cycle, open coding was done, with a view to "conceptualizing all related incidents in order to yield many concepts" (Savin-Baden \& Major, 2013). During this cycle, I also employed what Saldaña (2009) terms "simultaneous coding" where two or more different codes were applicable to one single qualitative datum, or when there were overlapping aspects among the data. During the second cycle, a method called "axial coding" (Savin-Baden \& Major, 2013) was used. This approach to coding, as they put it, "requires focusing on causal relationships and seeking to categorize incidents into a frame that structures generic relationships" (p. 424). This second cycle of coding resulted in two major categories: the first one distinguishes between the participant's organizational time/ space and experienced time/space, whereas the second one suggested three ways in which these two types of time and space are connected or separated.

In the process of data analysis, a categorical-content approach to narrative analysis, as defined by Lieblich, TuvalMashiach, and Zilber (1998), was employed. Excerpts were scrutinized in order to discover different aspects of the subject's experiences. Finally, the interpretation process was done with careful reference to the conceptual framework, in such a way that the findings would be congruent with the literature.

\section{Findings and discussions}

\subsection{Findings}

\subsubsection{The organizational time and space}

"... in the physical campus... I know that they've got good sports facilities”
The PGCE course that Gaz is taking is a one-year course started in August 2017. Gaz mentioned it as a combination of both synchronous and recorded lectures. Specifically, it consists of three 80-hour modules, each with a three-hour recorded presentation, reading tasks and online conferences, which are broken down into smaller time slots.

In terms of space, Gaz referred to the Moodle where conferences take place, an online library and the Googlegroups where students discuss questions. He does not know the physical university exactly, but remarked:

I intuitively know it's a very popular university. It's been around for ages. And, everyone in England knows the university; so in the physical campus, I'm sure, I know that they've got good sports facilities.

Gaz mentioned a number of on-campus facilities and activities in the organizational space which he believes to be also available to students taking this online course, were they to live in the city of the university. For example, "you are still able to go into the university, meet with the professors face to face, you can use their library, their facilities, join their sports team, everything like that". However, as he is currently a distance student, such aspects of the organizational space are rendered unavailable to him.

\subsubsection{The experienced time and space \\ "We've got kid's stuff all over the floor"}

The most part of Gaz's study is done at home, on his couch, which he described as:

It's very messy. The moment we've got kids' stuff all over the floor ... it's my home, it's where I'd like to be. If I need a break, I can go and, I can put the TV on, I can choose when to study. 
Other times when he has got students doing their tests, Gaz "brings" his virtual classroom into the physical classroom where he teaches by doing the readings required by the course there. In a past module about classroom management, his virtual study space was present in his colleagues's classrooms, where he was required to observe them teaching and guide them on teaching methodologies.

Gaz does not have a fixed schedule. His experienced study time depends on his mood, which leads to him sometimes studying for the whole night and yet sometimes pausing for weeks, "skip[ping] out a lot of the reading". However, he estimates his average amount of study time to be approximately ten hours a week. Unless interrupted, he will complete the sessions each time he studies. Gaz is working fulltime at school; therefore, his study is usually done at night.

Gaz's experienced time and space of study are in general not those purposefully arranged for studying, but rather mingled with the time and space of his daily activities. These shared times and spaces entail a number of distractions. Therefore, although he seemingly has his own preferences regarding the time and space of studying, there is hardly a strict separation between his study and his personal duties owing to this squeeze of time and space.

\subsubsection{Factors affecting the connectedness} and separation between the organizational time/space and the experienced time/space

From Gaz's sharing about his experience, three major factors were identified to explain for the connectedness or separation aspects between his experienced time/space and the organized time/space of the university.

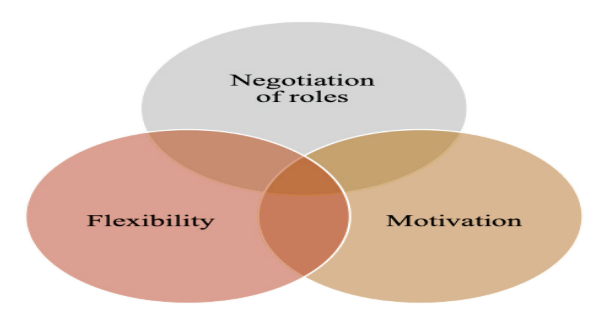

Figure 1. Factors affecting the connectedness and separation of organizational time/ space and experienced time/space in online distance education

\section{Flexibility}

"It's really broken down to literally each activity"

The PGCE course offers several features that connect the students with the course in terms of time and space. Regarding the temporal aspect, it has a good balance between synchronous and asynchronous study activities, and in case a student misses a particular online session, a recorded version is available for them to follow up. In addition, Gaz appreciated the way the course is really "broken down to literally each activity", keeping the learners on track with what has been planned. Although there is a six or seven time zone difference between where Gaz lives and the physical campus, he personally finds it suitable as he considers himself "a night person". The afternoon time of the online conferences happens to fall at around 10p.m local time of his, which is also the time he regularly sets aside for his study. Moreover, the organized space as he described is based on a platform that is "easy to navigate around, and ... very simple to use" with downloadable materials and the Googlegroups where: "If we don't understand anything, we can quickly bring up the question there, and there're twenty of the students ready to answer". The Googlegroups is in fact what he considers 
effective, as students are judged on their interaction with their peers, and "[i]f you don't talk, then you'll get lower marks". Besides, although the university is not physically present where he lives, the online library makes him connected with it by "being able to get a book whenever [he] likes". He did contemplate being "in the city of the university, then you are still able to go into the university, meet with the professors face to face, you can use their library, their facilities, join their sports team, everything like that".

\section{Motivation}

"The Googlegroups are really friendly and helpful"

Gaz's motivation has been a factor responsible for how he engages his time and space with the time and space of the course. $\mathrm{He}$ confessed undergoing fluctuations in interest, which affects the frequency and amount of time he spares for his study. He further added that "it depends. It's more when I feel like it. And sometimes ... I do sit down the night, or sometimes I do nothing for two weeks". Another important source of motivation for him came from his classmates. He admitted being pushed to speed up his work to catch up with the deadline when seeing his peers posting on Googlegroups "two or three topics, ahead of what [he was] doing". Although he agreed that communication is "different with the time difference", he was fascinated by the fact that there are two other students from Vietnam who are also in this course, which made him see this experience as very similar to being at a campus. However, he sees the fact of not knowing his classmates as individuals a slightly demotivating factor, as "it's easier to respect to people's opinions when you can go and have a drink with them, getting to know them as people". In this sense, the separation between the organized space and his experienced space somehow affected his motivation in the course.

\section{Negotiation of roles}

The fact that Gaz is performing several other roles apart from being an online student both connects and separates his experienced time and space from the organized time and space of the course.

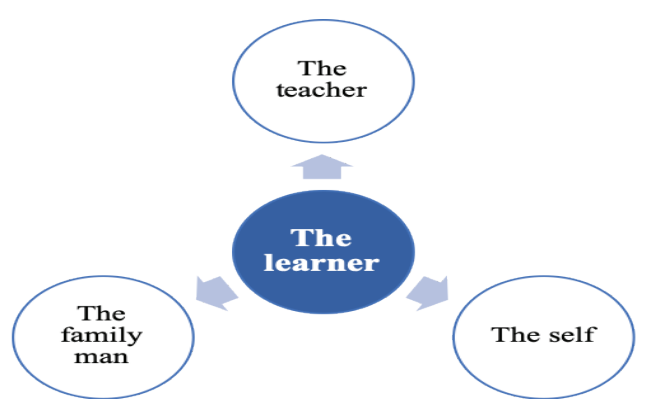

Figure 2. Simultaneous roles of the adult online learner

\section{The family man}

"We were just wishing and praying that he would hold on for another couple of weeks..."

Gaz's online course coincides with his first time being a father. His course time was most separated from his experienced time when assignment deadline was waiting for him and his baby was about to be born. All that he could do then was "just wishing and praying that he (the baby) would hold on for another couple of weeks, so, ... I'll be able to get my assignment done before I had a kicking screaming baby", as he shared. Besides the fact that his studying place with "kids' stuff all over the floor" is totally different from the image of a classroom, his baby is also "a big interruption" that separates his times. Gaz prioritizes his baby, admitting that his studying might be interrupted because "he (the baby) comes first. If he's awake and crying, I'll go and look after him". 
However, as a family man, Gaz also received much support from his wife, which is a critical factor to keep him connected to the organizational time of the course. His wife, who is also a teacher of English, usually assisted him with his assignments or looked after the baby when the deadlines are close. In that way, Gaz could keep pace with his course schedule. "She knows how important it is for our lives, to have a better life for our kid, to get completed", he remarked.

\section{The teacher}

"There's constantly the call in the back of my mind"

Gaz's job as a teacher constitutes a part of the course time. An example was when he conducted observations in his colleagues' classes as he studied the module about classroom management. It reveals here an obvious connection between his experienced time and the organized time. Nevertheless, as a teacher, he also has to fulfill schoolwork, which at times separates him from the course time.

... so again I've got three hundred students, so I've got to write reports to them all and at those times, I don't have any time to do any study.

Negotiating between work and study for him was quite hard sometimes:

... of course when the assignment's due in two weeks, you don't want to go to work, you've got to get your assignment done. Erm, and then especially when the class really starts to get really messing around, there's constantly the call in the back of my mind, I really just want to work out so I can do my study. Erm, so, yeah, I feel at times that my office work at school has been inadequate, because I've had to do more uni work, and my uni work has been inadequate at times because I have to do more schoolwork.

\section{The self}

"I have to stop going to the Jujutsu"

To arrange his time for the course, Gaz has to give up his martial art class and spend less time going out so that he can get his work done. His personal life also does not allow him to complete the course according to the planned time as there was an incident that affected him "not to be able to concentrate or carry on with [his] study". He therefore had to ask for a mitigation and was behind the organized time.

\section{Others}

\section{"The sharks like to eat the cable"}

Gaz mentioned a particular situation that happened to him "about six times in the past two years". As he said, the government "decide to slow down the Internet so ... the people are less informed" when there is a political movement. He was temporarily disconnected from the time and space of his online course at that time, yet he resolved by "look[ing] at all the links and print them out for the modules, so I've always got like stacks of papers to read upon if the Internet was slow".

\subsection{Discussion}

Being a distance student, Gaz is situated between different locales where he undergoes the "translocal" and "transtemporal" experiences. Although the university he attends is over 5,000 miles from where he lives, his stories have shown that he has had "a common state of being, or feeling, connected" to it in various aspects (Sheail, 2017). The university exists on his couch, in his room full of kids' toys and at times in the school where he works. The times spent on his course is sometimes in conflict with the time he is supposed to spare for his students, his newborn baby, or his hobbies. His university is 
sometimes double connected with him in time and space when he is able to meet a classmate living in the same city. Other times when the sharks feel like "eating the cable", his experienced time and space are temporarily suspended from the university's time and space until he is electronically reconnected. A number of factors, both material and spiritual, have determined such connectedness and separation, with the most outstanding being the flexible organization of the course, his personal motivation and the multiple roles that he plays simultaneously with being an online student.

First, the flexibility of the course entails an easy navigation within the platform and thoughtful allotments of time according to study activities, in a way that keeps students in the same pace with the organizational time and space as designed by the course. The discussion board activities, which are also the topic of concern of Khoo and Cowie (2014) and Oztok et al. (2014), a.o., can as well contribute to building productive learning relationships. More broadly speaking, flexibility should involve granting access to a variety of facilities and activities available on campus to students taking the course online. Considering Gaz's appreciation of the way the e-library keeps him connected with his alma mater spatially, the idea is worthy of attention. When linked with one of the topologies of the digital university, "campus envy" (cf. Bayne et al., 2014), it becomes even more obvious that the physical campus still holds a dominant position in the online learners' conception of space. Therefore, any efforts to render the online experience most equitable with the on-campus experience will be essential in making the students feel connected temporally and spatially.

Secondly, motivation is as important in initiating a student status as in maintaining the online students' connectedness with the course. Each student can have their own sentimental association with the course and the university they choose to enroll in (cf. Bayne et al., 2014), which makes them feel attached. In Gaz's sharing, motivation necessarily comes from his classmates, who sped him up to catch up with the deadlines, or some of whom he happened to know in person and made him feel as connected as being on campus. However, as shared by Gaz and a number of other studies, motivation is usually found to fluctuate as students progress further in the course (e.g., Ross et al., 2013; Rye \& Støkken, 2012). Knowing what (de) motivates online students could thus be a topic for future research.

Finally, the various social roles a student assumes can both promote and demote their connectedness with the online course in terms of time and space. This finding is very much in line with Fielding (2016); Ross et al. (2013); Rye and Støkken (2012), a.o., who viewed the online course as an ongoing negotiation in which students constantly attempt to fit the study activities into their actual lived experience. In this struggle, the students, including Gaz, often find themselves carving out space and time for the course by deciding on their priorities for each period of time. At the same time, however, being part of the social relationships places the students in both spiritual and material support. The studies outlined above and Gaz's experience showed how concrete actions of family members, such as helping out with household duties, contribute to keeping the students in tune with their course organization.

Insofar as a sense of separation is inherently existent in the practice of online distance education, it should therefore be seen as an opportunity to exercise one's self-control and autonomy, while being able to pursue their 
studies alongside other social roles (Raddon, 2006). On the other hand, connecting the students' lived experiences, both temporally and spatially, to the organizational time and space of the university, is essential. Students can be made more involved when there are flexible, engaging curricular (as well as non-curricular) activities, when there are both policies that encourage communication and varied support services to offer timely assistance. Finally, it is crucial that any course designers keep in mind the complexities of the local experience of the students, so that they can maintain a balance between the convenience of the university and that of the students.

\section{Concluding remarks}

To sum up, the present study has suggested that the times and spaces of the online learning programme are socially constructed, moving beyond the temporal and spatial boundaries of the commonly perceived image of an educational institution. As remarked by Fielding (2016), an online learner "will have to fit a course into his or her actual, lived experience, engaging in an ongoing negotiation between the parts of their lives as they decide what specific times they will use for their online coursework, and what else they will not do...” (p. 104). Taking into account the multiple locales and temporalities in which the learners reside will render them more visible in considering the design and services of the online courses. To do this is to contribute to a more egalitarian status quo of the online distance "university", as opposed to the physical campus. The university then will be seen as "opens up", instead of "reaches out" across distances, to quote Sheail's words.

\section{References}

Barberà, E., \& Clarà, M. (2012). Time in e-learning research: A qualitative review of the empirical consideration of time in research into e-learning ISRN Education, 2012, 1-11. https://doi. org/10.5402/2012/640802

Barberà, E., \& Clarà, M. (2014). The temporal dimensions of e-learning. E-Learning and Digital Media, 11(2), 105-107. https://doi.org/10.2304/ elea.2014.11.2.105

Barberà, E., Gros, B., \& Kirschner, pa. (2015). Paradox of time in research on educational technology. Time \& Society, 24(1), 96-108. https://doi. org/10.1177/0961463X14522178

Bayne, S., Gallagher, S. M., \& Lamb, J. (2014). Being "at" university: The social topologies of distance students. Higher Education: The International Journal of Higher Education and Educational Planning, 67(5), 569-583. https://doi.org/10.1007/s 10734-0 13-9662-4

Clandinin, D. J., \& Connelly, F. M. (2000). Narrative inquiry: Experience and story in qualitative research. San Francisco: Jossey-Bass.

Fielding, H. (2016). "Any time, any place": The myth of universal access and the semiprivate space of online education. Computers and Composition, 40, 103-114. https://doi.org/10.1016/j. compcom.2016.03.002

Flick, U. (2014). An introduction to qualitative research (5th ed.). London: Sage.

Freeman, M. (2006). Life “on holiday?” Narrative Inquiry, 16(1), 131-138. https://doi.org/10.1075/ bct.6.16fre

Freeman, M. (2015). Narrative as a mode of understanding. Method, theory, praxis. In A. De Fina \& A. Georgakopoulou (Eds.), The handbook of narrative analysis (1st ed., pp. 21-37).

Greiner, C., \& Sakdapolrak, P. (2013). Translocality: Concepts, applications and emerging research perspectives. Geography Compass, 7(5), 373-384. https://doi.org/10.1111/gec3.12048

Hall, E. T. (1983). The dance of life: The other dimension of time. Garden City, NY: Anchor Press/Doubleday.

Kabat, K. J. (2014). Time, space, and dialogue in a distance-learning class discussion board. $E$ Learning and Digital Media, 11(2), 162-175.

Kahu, E. R., Stephens, C., Zepke, N., \& Leach, L. (2014). Space and time to engage: Mature-aged distance students learn to fit study into their lives. International Journal of Lifelong Education, 33(4), 523-540. https://doi.org/10.1080/02601370.2014.8 84177

Khoo, E., \& Cowie, B. (2014). But the learning has already passed: Rethinking the role of time in e-mediated learning settings. E-Learning and Digital Media, 11(2), 176-190. https://doi.org/10.2304/ elea.2014.11.2.176

Leeds, B. (2014). Temporal experiences of e-learning by distance learners. Education + Training, 56(2/3), 179-189. https://doi.org/10.1108/ET-11-2012-0114

Lieblich, A., Tuval-Mashiach, R., \& Zilber, T. B. 
(1998). Narrative research: Reading, analysis and interpretation. Thousand Oaks, CA: Sage.

O'Shea, S. (2014). Transitions and turning points: Exploring how first-in-family female students story their transition to university and student identity formation. International Journal of Qualitative Studies in Education, 27(2), 135-158.

Oztok, M., Wilton, L., Lee, K., Zingaro, D., Mackinnon, K., Makos, A., ... Hewitt, J. (2014). Polysynchronous: Dialogic construction of time in online learning. E-Learning and Digital Media, 11(2), 154-161. https://doi.org/10.2304/elea.2014.11.2.154

Raddon, A. (2006). Absence as opportunity: Learning outside the institutional space and time [Online version]. Journal of Further and Higher Education, 30(2), 157-167. https://doi. org/10.1080/03098770600617596
Ross, J., Gallagher, M. S., \& Macleod, H. (2013). Making distance visible: Assembling nearness in an online distance learning programme. International Review of Research in Open and Distance Learning, 14(4), 51-67. https://doi.org/10.19173/irrodl. v14i4.1545

Rye, S. A., \& Støkken, A. M. (2012). The implications of the local context in global online education. 13(1), 16.

Saldaña, J. (2009). The coding manual for qualitative researchers (1st ed.). London: Sage Publications.

Savin-Baden, M., \& Major, C. H. (2013). Qualitative research: The essential guide to theory and practice. London: Routledge.

Sheail, P. (2017). The digital university and the shifting time-space of the campus. Learning, Media and Technology, 43(1). https://doi.org/10.1080/1743988 4.2017.1387139

\title{
SỰ KẾT NỐI GIŨ๋A THỜI GIAN/KHÔNG GIAN TỔ CHỨC VA் THÒ̀I GIAN/KHÔNG GIAN TRẢI NGHIẸM, QUA GÓC NHİN CỦA MỘT HỌC VIÊN TRỰC TUYẾN TỬ XA
}

\author{
Trần Thị Ngân \\ Truờng Đại hoc Ngoại ngũ - ĐHQGHN, \\ Phạm Văn Đồng, Cầu Giấy, Hà Nội, Việt Nam
}

Tóm tắt: Nghiên cứu này đặt vấn đề về cách nhìn nhận không gian và thời gian trong giáo dục trực tuyến từ xa. Nghiên cứu lập luận rằng giáo dục trực tuyến từ xa được cấu thành bởi các loại thời gian và không gian khác nhau, cụ thể là thời gian/không gian thiết lập bởi các cơ sở đào tạo, và thời gian/không gian qua trải nghiệm thực tế của người học. Mục tiêu của nghiên cứu là chỉ ra sự kết nối cũng như tách biệt giữa hai loại không gian/thời gian này. Bằng phương pháp định tính sử dụng hình thức điều tra tường thuật, nghiên cứu đã tìm hiểu sâu về trải nghiệm của một học viên 32 tuổi người Anh sống tại Việt Nam đang theo học một khóa học từ xa tại Anh Quốc. Qua đó, nghiên cứu hướng tới tìm ra những yếu tố liên kết người học về mặt không gian và thời gian với khóa học mà họ theo đuổi, cũng như những yếu tố tạo nên khoảng cách trên hai khía cạnh này. Qua những trải nghiệm thực tế của người học, các cơ sở đào tạo có thể xem xét kỹ lưỡng hơn cách thức tổ chức hiệu quả các khóa học trực tuyến từ xa, nhằm nâng cao động lực cũng như sự cam kết của học viên, đồng thời góp phần tạo nên những trải nghiệm tích cực của họ về học tập kỹ thuật số.

Tù khóa: sự liên kết, không gian và thời gian, liên không gian, liên thời gian, giáo dục trực tuyến từ xa, giáo dục kỹ thuật số 


\section{Appendix}

Interview Protocol

Part 1: General questions

1. Could you please introduce yourself a bit? (your name, age, country of origin, country of current residence, your job and workplace, people living with you at the moment, etc.)

2. Could you tell me about your educational profile in general?

3. Could you please briefly describe the course that you are taking?

- Name

- Main contents

- Duration

- How long is the course?

- When did you start it?

- Requirements

- Evaluation (exams/ tests/ assignments etc.)

- Does it offer any kind of certificate?

- Is it a synchronous online course (one with live lectures) or a recorded one?

4. What was your purpose of taking this course? Was it for personal or professional purposes?

Have you accomplished it or not? Why/ Why not? (If you have more than one purpose, please mention all of them).

5. How did you come to know about the course and the institution? What made you decide to enroll in this particular course and institution?

6. Is this your first online course, or did you have prior experience with online learning?

7. Why didn't you choose a face-to-face course instead of this one?

8. Are you working or studying simultaneously with taking this course?

9. How do you assess your level of commitment with the course? (highly committed, quite committed, not so committed, etc.)

Some examples include:

- Doing the assigned tasks in the course

- Revising learnt lessons

- Communication with the instructors/ fellow students

10. What is your general feeling/opinion of the experience of taking this course? (e.g., freedom and flexibility, discovering new things, etc. - can be both positive and negative). Is it the same or different from your initial expectations before taking the course? In what way?

Part 2: Main questions

Explanation of key concepts:

- The organizational time and space refer to the time and space as designed by the course providers. The organizational time includes, for example, the total number 
of hours required, the time allocated to each module and other learning activities, such as self-study, homework, assignments, assessment tasks, etc., and also the real time in the institution where the course is based. The organizational space involves the classroom where the lectures take place and the learning platform on which the course is organized, for example the presentation and access of learning modules, communication tools, etc.

- The experienced time and space refer to your real life time and space when doing the course. Your experienced time can involve the time you set aside for studying the course, how you arrange your study activities and fit them in your daily schedules. Your experienced space is where your study takes place and its surroundings, as well as facilities needed for your study. In a broader sense, your experienced time and space also include the current socio-political situation of the country where you are residing, should they have any impact on your online learning experience.

1. Organizational time

How is the course that you took organized?

- What is the total amount of time as designed by the course providers?

- How many modules are there? How much time is allocated for each module?

- What other learning activities are there in the course? (reading, quiz, homework, assignments, tests, etc.) How much time is required of each of these activities?

2. Experienced time

- How much time do you set aside each week/each day for the course? Is that sufficient compared to the required amount of time as set by the course providers?

- During what time of the day do you study? (If yours is a synchronous course, please mention also the time in the situation where it is based, e.g., if it's in a different time zone from yours).

- Is your studying time fixed and each study session relatively equal? Why/Why not?

- Do you complete each unit/section within each study session, or do you split it up and complete in several sessions? If your answer is the latter, why?

- Have you ever encountered any interruptions during your study? If yes, what were they, why did they happen and how did you handle them?

- If you are working or studying while taking this course:

- Does studying the course anyhow affect your daily life? (if yes, in what way?)

- In reverse, does your lifestyle have any impact on how you schedule your study activities?

- How do you make up for the time spent on this course while managing to fulfil tasks at work/school/home?

3. Compared between the organizational time and your own experienced time, what do you see as the most striking difference(s)?

What causes the difference(s), in your opinion?

Did you expect such difference(s) before taking the course? 
4. Organizational space

How do you describe the organizational space of the course that you took?

- What is the classroom like? What facilities are there?

- What is the online learning platform on which the course is organized like?

- Appearance: How are the modules presented? Your comments (e.g., if it's userfriendly, etc.)

- Functions: Besides the presentation of the course contents, what other functions are there in the platform? (e.g., discussion board, assistant tools, dictionary, library, etc.) How do they support your study?

- How do you comment on the general atmosphere that you feel about the online space of the course?

- How do you compare the space of the online course with the physical campus of the previous institution that you attended? What aspects are retained and what aspects are missing?

- Personally, what do you prefer, the physical campus or the virtual space of the online course? Why?

\section{Experienced space}

How do you describe your own experienced space?

- Where do you often study your online course? (for example, in your own room, in a café, in your office working desk, in your car, etc.)

- What is/are the place(s) like?

- What facilities/tools are there to support your study and what does not support?

- What aspects of a classroom do you not have in your study place?

- Are your places of study fixed or flexible at your convenience? Why?

- Are there any distractions in your studying place? (e.g., at your office desk $\rightarrow$ coworkers chattering, people moving around, etc.) If yes, how often are they and how do you manage to overcome them?

- How do you comment on the general atmosphere that you feel about your chosen place(s) of study?

6. Interaction with the people involved in your online study, in terms of both time and space

- How do you interact with the course instructors, course organizers as well as other students? (By what means, e.g., email, discussion board, etc.)

- Can you describe the experience?

- More details about each group of people:

Communication with instructors:

○ Do they have fixed contacting hours (compared with office hours)?

- Are they in the same or different time zone with you?

○ How long does it usually take for your questions to be responded?

Communication with other class members:

- If you are using a discussion board, for example, (or any kinds of forum) what 
do you use this means of communication for? (e.g., assignments, exchanging views about the topic of study, etc.)

- How do you compare it with face-to-face discussions? (in terms of time, space and interaction)

- Are your classmates from the same country with you?

- Do they and you communicate effectively and in a timely manner by the designated means of communication?

Communication with course organizers:

- Do you ever have to contact the course organizers?

- If yes, by what means and how long does it usually take them to respond?

- Other means of communication if come up.

7. What are your main sources of motivation in taking this course?

- From the course content?

- From your initial purpose?

- From the instructors (knowledge, teaching style, inspiration, etc.)?

- From other peers?

- From the online learning platform (attractive/friendly layout, convenient access, helpful customer care services, etc.)

8. What aspects of the course make you feel connected with or separated from it?

Please talk about both the "connectedness" and "separation" aspects.

- Prompts:

- The course contents

- The flexibility when taking the course (time/space)

○ The communication (e.g., discussions, support services, etc.)

- Your visibility with respect to the physical campus (e.g., participation in clubs, committees, etc.)

○ Etc.

- Does your feeling of connectedness or separation anyhow affect your study of the course (either positively or negatively)? How and to what extent?

9. Do you encounter any (other) difficulties with your personal time and space of study while doing your online course? If yes, what are they and how do you manage to overcome them?

E.g.: Internet connection, fatigue and stress (due to handling multiple duties), etc.

10. Do you have any plan to take a similar online course in the future?

11. If you could have any suggestions to improve on the course that you took, what would you say?

12. What do you think they could do to make the students feel more connected or more engaged in their studying in the online course?

13. Do you have any other comments/questions regarding our research? 